\title{
ITGA6 Gene
}

National Cancer Institute

\section{Source}

National Cancer Institute. IT GA6 Gene. NCI Thesaurus. Code C122059.

This gene plays a role in both laminin binding and cell adhesion. 